\title{
The Potential Roles of Bacterial Communities in Coral Defence: A Case Study at Talang-Talang Reef
}

\author{
Felicity W. I. Kuek ${ }^{1 *}$, Li-Fang Lim ${ }^{1}$, Lin-Hui Ngu ${ }^{1}$, Aazani Mujahid ${ }^{2}$, Po-Teen Lim ${ }^{3}$, Chui-Pin Leaw ${ }^{3}$, \\ and Moritz Müller ${ }^{1}$ \\ ${ }^{1}$ Faculty of Engineering, Computing and Science, Swinburne University of Technology, Sarawak campus, 93350 Kuching, Sarawak, \\ Malaysia \\ ${ }^{2}$ Department of Aquatic Science, Faculty of Resource Science and Technology, Universiti Malaysia Sarawak, 93400 Kota \\ Samarahan, Sarawak, Malaysia \\ ${ }^{3}$ Bachok Marine Research Station, Institute of Ocean and Earth Science, University of Malaya, 16310 Bachok, Kelantan, Malaysia
}

Received 30 June 2014; Revised 4 January 2015; Accepted 9 April 2015

(C) KSO, KIOST and Springer 2015

\begin{abstract}
Complex microbial communities are known to exert significant influence over coral reef ecosystems. The TalangSatang National Park is situated off the coast of Sematan and is one of the most diverse ecosystems found off-Sarawak. Interestingly, the Talang-talang reef thrives at above-average temperatures of 28 $30^{\circ} \mathrm{C}$ throughout the year. Through isolation and identification (16S rRNA) of native microbes from the coral, the surface mucus layer (SML), as well as the surrounding sediment and waters, we were able to determine the species composition and abundance of the culturable bacteria in the coral reef ecosystem. Isolates found attached to the coral are related mostly to Vibrio spp., presumably attached to the mucus from the water column and surrounding sediment. Pathogenic Vibrio spp. and Bacillus spp. were dominant amongst the isolates from the water column and sediment, while known coral pathogens responsible for coral bleaching, Vibrio coralliilyticus and Vibrio shiloi, were isolated from the coral SML and sediment samples respectively. Coral SML isolates were found to be closely related to known nitrogen fixers and antibiotic producers with tolerance towards elevated temperatures and heavy metal contamination, offering a possible explanation why the local corals are able to thrive in higher than usual temperatures. This specialized microbiota may be important for protecting the corals from pathogens by occupying entry niches and/or through the production of secondary metabolites such as antibiotics. The communities from the coral SML were tested against each other at 28,30 and $32^{\circ} \mathrm{C}$, and were also assessed for the presence of type I modular polyketides synthase (PKS) and non-ribosomal peptide synthetase (NRPS) genes which are both involved in the production of antibiotic compounds. The bacterial community from the SML exhibited antimicrobial properties under normal temperatures
\end{abstract}

*Corresponding author. E-mail: felicity.kuek@gmail.com while pathogenic strains appeared toxic at elevated temperatures and our results highlight the role of the coral SML bacterial community in the coral's defence.

Key words - bacterial communities, coral mucus, antimicrobial, increasing temperatures, coral reefs

\section{Introduction}

Coral reefs are a rare feature in Sarawak due to its shallow sea shelf extending a long way into the ocean, and are limited to the areas off the shores of Bintulu, Miri and offshore islands including the Talang-Satang National Park in Kuching. The Talang-Satang National Park is situated off the coast of Sematan and is especially important as it is one of the most diverse ecosystems found off Sarawak (Pilcher and Cabanban 2000).

Worldwide coral decline has been attributed to the increase of sea surface temperatures, coastal degradation, pollution, diseases, ecosystem imbalance caused by anthropogenic influences, and the synergistic effect of multiple stressors (Harvell et al. 2002; Rosenberg and Ben-Haim 2002; Sutherland et al. 2004). These make them extremely susceptible to outbreaks of coral diseases, whereby the immunity of corals decreases (Baker et al. 2008; Goreau and Hayes 2008). The surface of living corals is covered by a mucoid material. This mucopolysacchride layer provides a matrix for bacterial colonization, allowing establishment of a 'normal' bacterial community (Ducklow and Mitchell 1979; Ritchie et al. 1994). 